\title{
The Use of Vertical Electrical Sounding (VES) for Subsurface Geophysical Investigation around Bomo Area, Kaduna State, Nigeria
}

\author{
${ }^{1}$ B.S. Jatau, ${ }^{2}$ N.O. Patrick, ${ }^{3}$ A. Baba and ${ }^{4}$ S.I, Fadele. \\ ${ }^{1,2,3}$ Department of Geology and Mining, Nasarawa State University, Keffi. \\ ${ }^{4}$ Department of Physics (Applied Geophysics), Ahmadu Bello University, Zaria, Nigeria.
}

\begin{abstract}
Electrical resistivity investigation was carried out around Bomo area, Zaria, Kaduna state, in order to study the subsurface geologic layer with a view of determining the depth to the bedrock and thickness of the geologic layers. Vertical Electrical Sounding (VES) using Schlumberger array was carried out at fifteen (15) VES stations. ABEM terrameter (SAS 300) was used for the data acquisition. The field data obtained have been analysed using computer software (IPI2win) which gives an automatic interpretation of the apparent resistivity. The VES results revealed heterogeneous nature of the subsurface geological sequence. The geologic sequence beneath the study area is composed of hard pan top soil (clayey and sandy-lateritic), weathered layer, partly weathered or fractured basement and fresh basement. The resistivity value for the topsoil layer varies from $40 \Omega \mathrm{m}$ to $450 \Omega \mathrm{m}$ with thickness ranging from 1.25 to $7.5 \mathrm{~m}$. The weathered basement has resistivity values ranging from $50 \Omega \mathrm{m}$ to $593 \Omega \mathrm{m}$ and thickness of between 1.37 to $20.1 \mathrm{~m}$. The fractured basement has resistivity values ranging from $218 \Omega \mathrm{m}$ to $520 \Omega \mathrm{m}$ and thickness of between 12.9 to $26.3 \mathrm{~m}$. The fresh basement (bedrock) has resistivity values ranging from $1215 \Omega \mathrm{m}$ to $2150 \Omega \mathrm{m}$ with infinite depth. However, the depth from the earth's surface to the bedrock surface varies between 2.63 to $34.99 \mathrm{~m}$. The study further stressed the importance of the findings in civil engineering structures and groundwater prospecting.
\end{abstract}

Keywords: Electrical Resistivity, CERT (CT), Vertical Electrical sounding (VES), Top soil (TP), Weathered basement (WB), Partly Weathered Basement (PWB) and Fresh Basement (FB).

\section{INTRODUCTION}

The use of geophysics for engineering studies and water groundwater exploration has increased over the last few years due to the rapid advances in computer softwares and associated numerical modeling solutions. The Vertical Electrical Sounding (VES) has proved very popular with groundwater prospecting and engineering investigations due to simplicity of the techniques. The electrical geophysical survey method is the detection of the surface effects produced by the flow of electric current inside the earth. The electrical techniques have been used in a wide range of geophysical investigations such as mineral exploration, engineering studies, geothermal exploration, archeological investigations, permafrost mapping and geological mapping. Electrical methods are generally classified according to the energy source involved, i.e., natural or artificial. Thus, self potential (SP), telluric current come under natural source methods, while resistivity, electromagnetic (EM) and induced polarization (IP) methods are artificial source methods. The electrical d.c resistivity method used in carrying out the present survey is of artificial source using the ABEM terrameter (SAS 300). Appraising the hydrogeology in Zaria, Danladi (1985) has confirmed the presence of water bearing fractures,

which aquifers are located at a shallow basement area of Zaria. McCurry (1970), who studied the geology of Zaria, has established that the Basement Complex rock is made up of the Older Granite, Biotite granite-gneiss. Farouq (2001), carried out geoelectric investigation of the groundwater potential in the Institute for Agricultural Research Farm, Samaru, Zaria, showed that the thickness of the weathered basement around the area varies from 3.4 to $30.4 \mathrm{~m}$ and depth to fresh basement was $40 \mathrm{~m}$. Similarly, Saminu (1999), carried out a comprehensive geophysical survey over the premises of Federal College of Education, Zaria, showed that the thickness of the top soil of the area ranges between 3.5 and $14 \mathrm{~m}$ while the thickness of the weathered basement ranges between 9 and $36.5 \mathrm{~m}$. The depth to bedrock varies from 5 to $14 \mathrm{~m}$. In this study, geoelectrical investigations covering fifteen stations have been carried out and interpreted fully around Bomo area, Kaduna State, Nigeria, in order to evaluate the subsurface geologic layer with a view of determining the depth to the bedrock and thickness of the geologic layers. The study further stressed the importance of the findings in civil engineering structures and groundwater prospecting. 
II.

\section{GEOLOGY OF THE STUDY AREA}

The study area is part of the NW basement terrain underlain by basement rocks of Precambrian age. They are mainly granites, gneisses, and schists. Oyawoye (1964) showed that there is structural relationship between this Basement Complex and the rest of the West African basement. This is partly due to the fact that the whole region was involved in a single set of orogenic episode, the Pan African orogeny, which left an imprint of structural similarity upon the rock units. The gneisses are found as small belts within the granite intrusions, and are also found east and west of the batholiths (McCurry, 1970). The biotite gneiss extends westwards to form a gradational boundary with the schist belt. The gneiss continues eastwards to some extent and is occasionally broken up by the Older Granite (Wright and McCurry, 1970).

\section{SITE DESCRIPTION}

The study area is bounded approximately by longitudes $7^{0} 36^{\prime} \mathrm{E}$ and $7^{0} 38^{\prime} \mathrm{E}$, latitudes $11^{0} 09^{\prime} \mathrm{N}$ and $11^{0} 11^{\prime} \mathrm{N}$ as shown in location map (Fig 1) with an average elevation of $685 \mathrm{~m}$ above sea level. The area falls within the semi-arid zone of Nigeria (Harold, 1970). It lies in the guinea savannah; the woodland vegetation is characterized by bushes generally less than $3 \mathrm{~m}$ high.

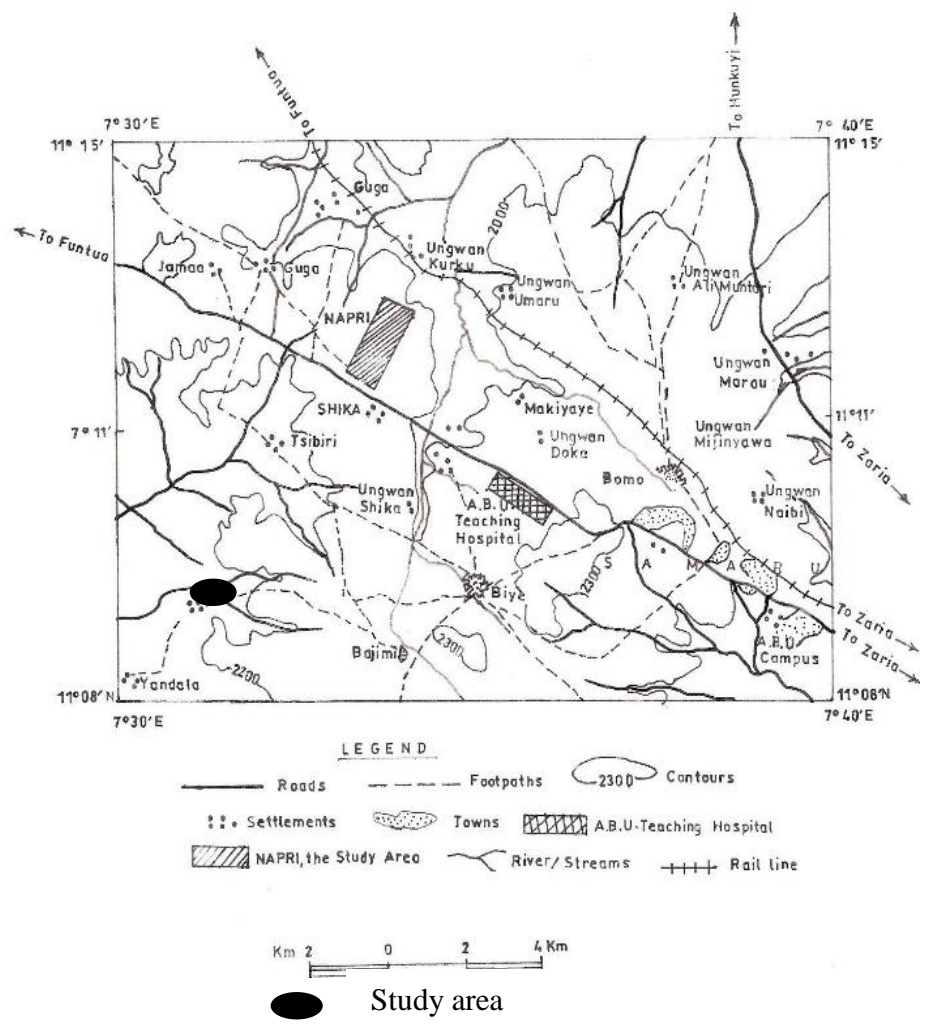

Fig 1: Location map showing the study area (from Northern Nigerian Survey Map)

\section{METHODOLOGY}

Vertical Electrical Soundings (VES) using Schlumberger array were carried out at fifteen (15) stations. A regular direction of $\mathrm{N}-\mathrm{S}$ azimuth was maintained in the orientation of the profiles. Overburden in the basement area is not as thick as to warrant large current electrode spacing for deeper penetration, therefore the largest Current electrode spacing $\mathrm{AB}$ used was $200 \mathrm{~m}$, that is, $1 / 2 \mathrm{AB}=100 \mathrm{~m}$. The principal instrument used for this survey is the ABEM (Signal Averaging System, (SAS 300) Terrameter. The resistance readings at every VES point were automatically displayed on the digital readout screen and then written down on the field note book.

\section{RESULTS AND DISCUSSION}

The geometric factor, $\mathrm{K}$, was first calculated for all the electrode spacings using the formula; $\mathrm{K}=\pi$ $\left(\mathrm{L}^{2} / 2 \mathrm{~b}-\mathrm{b} / 2\right)$, for Schlumberger array with $\mathrm{MN}=2 \mathrm{~b}$ and $1 / 2 \mathrm{AB}=\mathrm{L}$ (fig 2). The values obtained, were then multiplied with the resistance values to obtain the apparent resistivity, $\rho_{\mathrm{a}}$, values. Then the apparent resistivity, $\rho_{\mathrm{a}}$, values were plotted against the electrode spacings $(1 / 2 \mathrm{AB})$ on a log-log scale to obtain the VES sounding curves using an appropriate computer software IPI2win in the present study. Some sounding curves and their 
models are shown in Fig 3. Similarly, geoelectric sections are shown in Figs. 4 and 5. Three resistivity sounding curve types were obtained from the studied area and these are the H $\left(\rho_{1}>\rho_{2}<\rho_{3}\right), A\left(\rho_{1}<\rho_{2}<\rho_{3}\right)$ and KH $\left(\rho_{1}>\rho_{2}<\right.$ $\left.\rho_{3}>\rho_{4}\right)$ type curves. However, there are few points which show two geologic layer cases. The results of the interpreted VES curves are shown in Table 1. The modeling of the VES measurements carried out at fifteen (15) stations has been used to derive the geoelectric sections for the various profiles. These have revealed that there are mostly four and three geologic layers beneath each VES station, and two layer cases at three different VES point. The geologic sequence beneath the study area is composed of top soil, weathered basement, partly weathered/fractured basement, and fresh basement. The topsoil is composed of clayey and sandy-lateritic hard pan with resistivity values ranging from $40 \Omega \mathrm{m}$ to $450 \Omega \mathrm{m}$ and thickness varying from 1.25 to $7.5 \mathrm{~m}$., thinnest at VES 12 and thickest at VES 13. It is however, observed from the geoelectric sections that VES 1, 2, 7 and 10 are characterized with low resistivity values varying between $40 \Omega \mathrm{m}$ to $90 \Omega \mathrm{m}$ suggesting the clayey nature of the topsoil in these areas are possibly high moisture content. The second layer is the weathered basement with resistivity and thickness values varying between $50 \Omega \mathrm{m}$ and $593 \Omega \mathrm{m}$ and 1.37 to $20.1 \mathrm{~m}$ respectively. This layer is thickest at VES 2, suggesting this point for siting borehole but thinnest at VES 7 and 8. Other points with probable high water potentials suitable for siting borehole include: VES 3, 5, and 9 respectively with appreciable thickness of weathered rock also known as aquifferous zone. The third layer is the partly weathered and fractured basement with resistivity and thickness values varying between $218 \Omega \mathrm{m}$ to $520 \Omega \mathrm{m}$ and 12.9 to $26.3 \mathrm{~m}$ respectively. The layer is extensive and thickest at VES 3 and thinnest at VES 2 . The fourth layer is presumably fresh basement whose resistivity values vary from $1215 \Omega \mathrm{m}$ to $2150 \Omega \mathrm{m}$ with an infinite depth. However, the depth from the earth's surface to the bedrock surface varies between 2.63 to $34.99 \mathrm{~m}$, deepest at VES 2 and shallowest at VES 7.

\section{CONCLUSION}

Geoelectrical investigation using the d.c electrical resistivity method around Bomo area, Kaduna State, Nigeria, three and four geologic layers are delineated at the subsurface composed of top soil, weathered basement, partly weathered or fractured basement and fresh basement. Based on the qualitative interpretation of the VES data, it is deduced that VES Stations 2, 3, 5 and 9 are viable postions for siting boreholes with appreciable thickness of weathered and fractured basement (aquiferrous zone) ranging from 12.71 to $33 \mathrm{~m}$. This geologic layer is characterized by structural features like fractures, fissures or pore spaces that enhance groundwater permeability and storage hence suggesting these points for siting borehole. To ensure safety consumption of groundwater in the area, potential sources of contamination site should be sited far away from viable aquifer units because the area is vulnerable to pollution if there is leakage of buried underground septic tank, sewage channels or infiltration of leachate from decomposing refuse dumps in the area as a result of their shallow depth to the aquifferous zone ranging from 1.25 to $2.63 \mathrm{~m}$. It is also deduced that the area can support low to high engineering structures as a result of the thin clayey nature generally less than $2 \mathrm{~m}$ in most of the area underlain by basement rocks at shallow depth. The study area can support low to great engineering structures as a result of their shallow depths to the underlying rock which can serve as pillar supports to the building except for VES 13 and 15 which structural foundation requires little pilling because of the thick top soil.

Table 1: The results of the interpreted VES curves

\begin{tabular}{|c|c|c|c|c|c|}
\hline $\begin{array}{c}\text { VES } \\
\text { Stations }\end{array}$ & $\begin{array}{c}\text { Thickness } \\
\text { (m) }\end{array}$ & $\begin{array}{c}\text { Layer resistivity } \\
(\triangle \mathbf{m})\end{array}$ & Remarks & Curve types & Numb of layers \\
\hline CT15 & $\begin{array}{c}2.85 \\
6.86 \\
1.67 \\
3.33 \\
-\end{array}$ & $\begin{array}{c}87 \\
197 \\
1230 \\
70 \\
219 \\
2045\end{array}$ & $\begin{array}{c}\text { TP } \\
\text { WB } \\
\text { FB } \\
\text { TP } \\
\text { WB } \\
\text { FB }\end{array}$ & A & 3 \\
\hline 2 & $\begin{array}{c}1.99 \\
20.1 \\
12.90 \\
-\end{array}$ & $\begin{array}{c}55 \\
318 \\
218 \\
1396\end{array}$ & $\begin{array}{c}\text { TP } \\
\text { WB } \\
\text { PWB } \\
\text { FB }\end{array}$ & $\mathrm{KH}$ & 4 \\
\hline 3 & $\begin{array}{c}1.25 \\
6.05 \\
26.3 \\
-\end{array}$ & $\begin{array}{c}245 \\
190 \\
520 \\
1215\end{array}$ & $\begin{array}{c}\text { TP } \\
W B \\
\text { PWB } \\
\text { FB }\end{array}$ & $\mathrm{KH}$ & 4 \\
\hline 4 & $\begin{array}{l}1.24 \\
2.04 \\
-\end{array}$ & $\begin{array}{c}245 \\
180 \\
1930\end{array}$ & $\begin{array}{l}\text { TP } \\
\text { WB } \\
\text { FB }\end{array}$ & $\mathrm{H}$ & 3 \\
\hline 5 & $\begin{array}{c}2.02 \\
5.51 \\
17.4 \\
-\end{array}$ & $\begin{array}{c}304 \\
593 \\
408 \\
2019\end{array}$ & $\begin{array}{c}\text { TB } \\
\text { WB } \\
\text { PWB } \\
\text { FB }\end{array}$ & $\mathrm{KH}$ & 4 \\
\hline
\end{tabular}


The Use of Vertical Electrical Sounding (VES) for Subsurface Geophysical Investigation around

\begin{tabular}{|c|c|c|c|c|c|}
\hline $\begin{array}{c}\text { VES } \\
\text { Stations }\end{array}$ & $\begin{array}{l}\text { Thickness } \\
(\mathrm{m})\end{array}$ & $\begin{array}{c}\text { Layer } \\
\text { resistivity }(\square \mathrm{m})\end{array}$ & Remarks & Curve types & Numb of layers \\
\hline 6 & \begin{tabular}{l|l}
2.57 & \\
7.6 &
\end{tabular} & \begin{tabular}{|c|}
135 \\
523 \\
1520 \\
\end{tabular} & $\begin{array}{l}\text { TP } \\
\text { PWB } \\
\text { FB }\end{array}$ & A & 3 \\
\hline 7 & $\begin{array}{l}1.26 \\
1.37 \\
-\end{array}$ & $\begin{array}{l}40 \\
114 \\
1230\end{array}$ & $\begin{array}{l}\text { TP } \\
\text { WB } \\
\text { FB }\end{array}$ & A & 3 \\
\hline 8 & $\begin{array}{r}1.31 \\
1.37 \\
- \\
\end{array}$ & $\begin{array}{l}150 \\
114 \\
1280 \\
\end{array}$ & $\begin{array}{l}\text { TP } \\
\text { WB } \\
\text { FB } \\
\end{array}$ & A & 3 \\
\hline 9 & $\begin{array}{c}1.29 \\
12.71\end{array}$ & $\begin{array}{c}256 \\
391 \\
1450\end{array}$ & $\begin{array}{l}\mathrm{TP} \\
\mathrm{WB} \\
\mathrm{FB} \\
\end{array}$ & A & 3 \\
\hline 10 & $\begin{array}{l}1.50 \\
2.75\end{array}$ & $\begin{array}{c}90 \\
50 \\
1200\end{array}$ & $\begin{array}{l}\mathrm{TP} \\
\mathrm{WB} \\
\mathrm{FB}\end{array}$ & $\mathrm{H}$ & 3 \\
\hline 11 & $\begin{array}{l}3.00 \\
9.50\end{array}$ & $\begin{array}{r}350 \\
270 \\
1560\end{array}$ & $\begin{array}{l}\text { TB } \\
\text { WB } \\
\text { FB }\end{array}$ & $\mathrm{H}$ & 3 \\
\hline 12 & $\begin{array}{r}1.25 \\
4.75 \\
- \\
\end{array}$ & $\begin{array}{c}180 \\
90 \\
2150 \\
\end{array}$ & $\begin{array}{l}\text { TP } \\
\text { WB } \\
\text { FB } \\
\end{array}$ & $\mathrm{H}$ & 3 \\
\hline 13 & 7.50 & $\begin{array}{c}300 \\
1875\end{array}$ & $\begin{array}{l}\text { TP } \\
\text { FB }\end{array}$ & 2 Layer case & 2 \\
\hline 14 & $\begin{array}{c}3.50 \\
- \\
\end{array}$ & $\begin{array}{r}265 \\
1900 \\
\end{array}$ & $\begin{array}{l}\text { TB } \\
\text { FB }\end{array}$ & 2 Layer case & 2 \\
\hline 15 & 5.00 & $\begin{array}{c}450 \\
1545\end{array}$ & $\begin{array}{l}\text { TB } \\
\text { FB }\end{array}$ & 2 Laver case & 2 \\
\hline
\end{tabular}

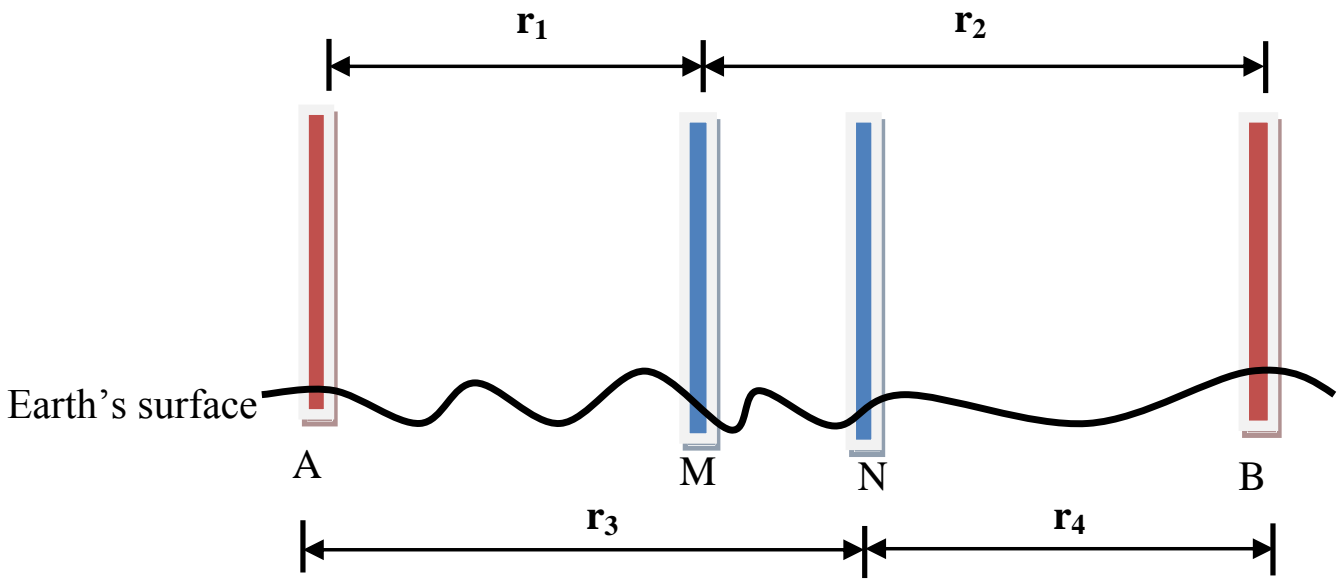

Figure 2: Four-general electrode configuration (Shlumberger Array)

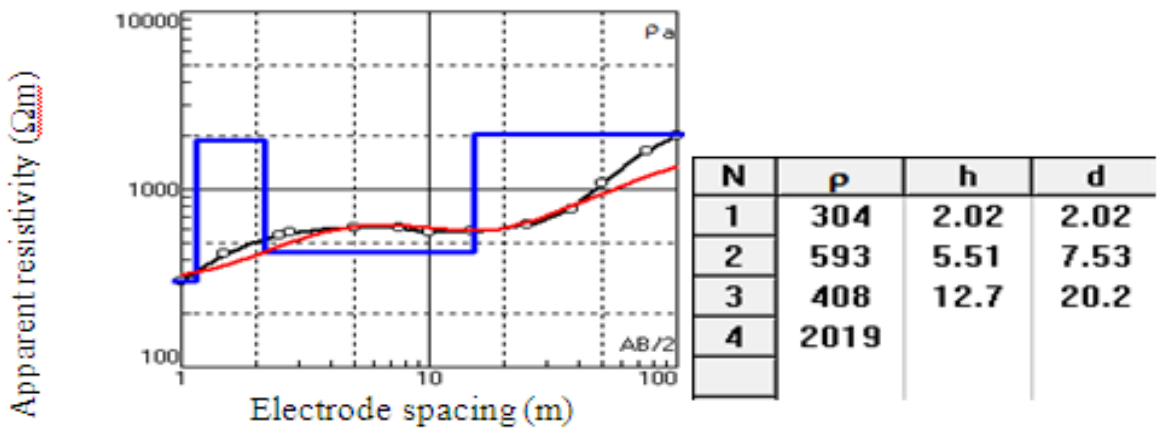

Where,

$\mathbf{N}$ is the number of layers,

7 is the apperent resistivity,

$\mathbf{h}$ is the thickness and

(a) VES Station 5 (TYPE KH CURVE) 


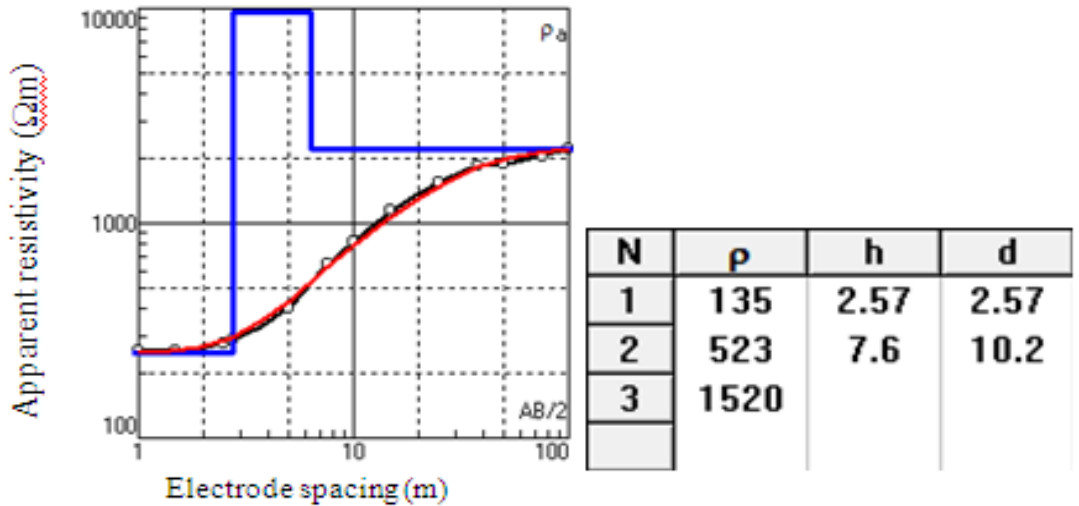

(b) VES Station 6 (TYPE A CURVE)

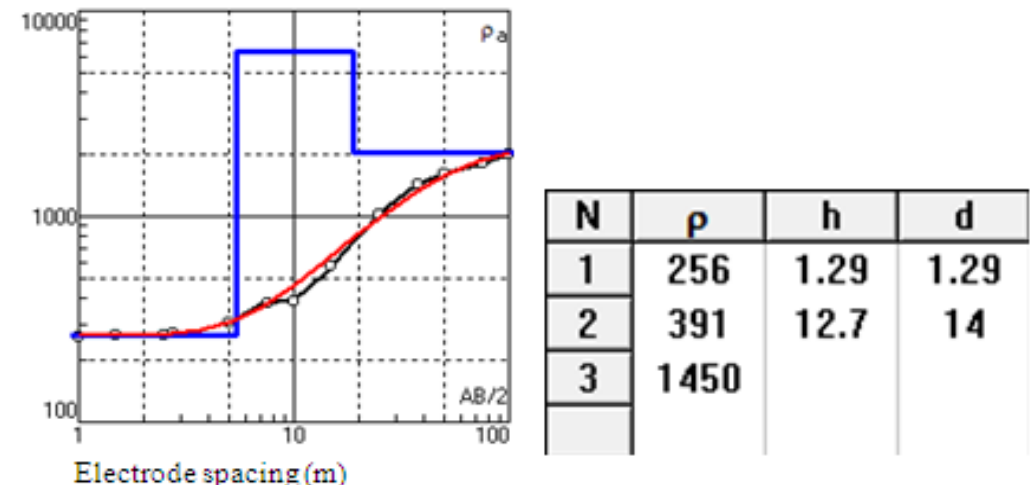

Where

$\mathbf{N}$ is the number of layers, $\square$ is the apperent resistivity,

$\mathbf{h}$ is the thickness and

d is the depth to interface
Where,

$\mathbf{N}$ is the layer number, … is the apperent resistivity

in ohm-metre,

$\mathbf{h}$ is the layer thickness and

(c) VES Station 9 (TYPE A CURVE)

FIG. 3: Typical curve types and models obtained from the study area.

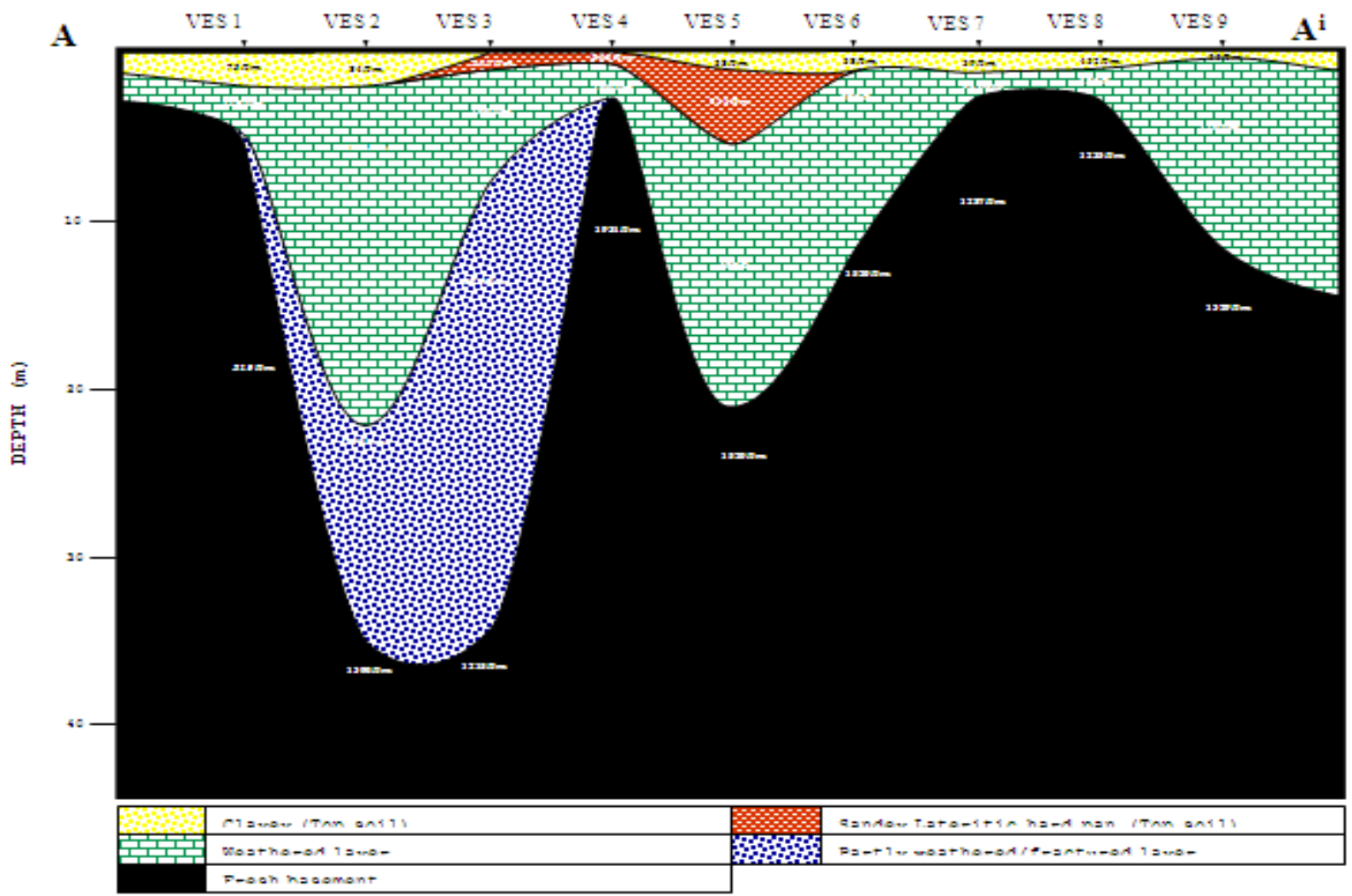

FIG. 4: Geoelectric section along profiles $A-A^{i}$ 


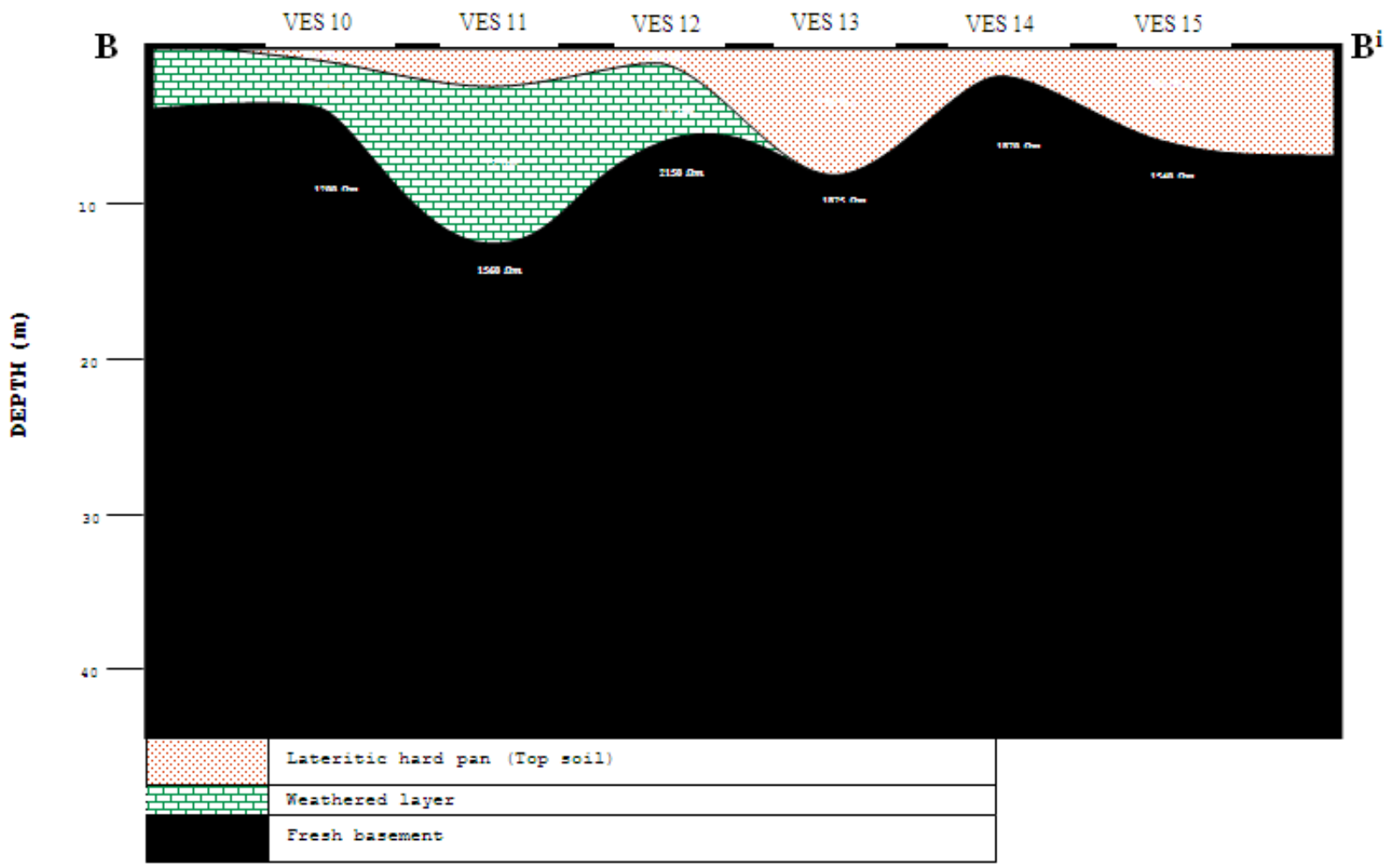

FIG. 5: Geoelectric section along profiles B-B

\section{REFERENCES}

[1] DANLADI, G.G. 1985. "Appraisal of Hydrological Investigation in Shallow Basement Area of Zaria". Unpublished M.Sc. Thesis, Department of Geology, Ahmadu Bello University, Zaria.

[2] FAROUQ, A.U. 2001. "Geoelectric Investigation of the groundwater potential in the Institute for Agricultural Research farm”. Unpublished M.Sc. Thesis, Department of Physics, Ahmadu Bello University, Zaria.

[3] HAROLD, E.D. 1970. “Arid Lands in Transition”. The Hornshafer Company Division of G.D.W. King Printing Co., U.S.A.

[4] KLINKENBERA, K. 1970. "Soil of Zaria Area, In Zaria and its Region” (ed. M. J. Mortimore), Department of Geography, Occasional Paper No. 4, Ahmadu Bello University, Zaria, P. 223 - 238.

[5] McCURRY, P. 1970. "The Geology of Zaria Sheet 21". Unpublished M.Sc. Thesis, Department of Geology, Ahmadu Bello University, Zaria.

[6] OYAWOYE, P. O. 1964. "Geology of Nigerian Basement Complex". Journal of Mining and Geology, Vol.1, P. 110-121

[7] SAMINU, O. 1999. "Geophysical Investigation of Federal College of Education, Zaria”. Unpublished M.Sc. Thesis, Department of Physics, Ahmadu Bello University, Zaria.

[8] WRIGHT, J. B. and McCURRY, P. (1970). "The geology of Nigeria Sheet 102 SW, Zaria and its regions. Edited by M. J. Mortimore. Department of Geography, Occasional paper, No. 4, Ahmadu Bello University, Zaria. 